\title{
ASSESSMENT OF INDOOR AIR QUALITY IN AN AIR-CONDITIONING SPLIT UNITS (ACSU) OFFICE BUILDING
}

\author{
NUR BAITUL IZATI RASLI*1, NOR AZAM RAMLI ${ }^{1}$, MOHAMMAD ZAIP AHMAD ${ }^{2}$ NURUL \\ ADILAH MOHD BADROLDIN ${ }^{2}$, AND MOHD RODZI ISMAIL ${ }^{3}$
}

${ }^{1}$ Environmental Assessment and Clean Air Research (EACAR), School of Civil Engineering, Engineering Campus, 14300 Nibong Tebal, Penang, Malaysia. ${ }^{2}$ Unit Keselamatan dan Kesihatan Pekerjaan Universiti, ${ }^{3}$ School of Housing Building and Planning, Universiti Sains Malaysia, 11800, Minden, Penang, Malaysia.

*Corresponding author: nurbaitulizati@gmail.com

Submitted final draft: 4 August $2020 \quad$ Accepted: 11 August 2020

http://doi.org/10.46754/jssm.2021.06.020

\begin{abstract}
The indoor air quality (IAQ) in Air-Conditioning Split Units (ACSU) offices depends mainly on recirculated indoor air that has gone through filters. Workers usually spend eight hours in the office space with restricted air circulation. An IAQ assessment was conducted at the administrative office space, USM, to investigate conditions in an ACSU office space; from 8.00 a.m. to $6.00 \mathrm{p} . \mathrm{m}$. It starts with a walkthrough survey followed by the filling of questionnaires, with a sample size of 11 workers for insights into the office operations. The specific physical parameters ( $\mathrm{T}, \mathrm{RH}$, and $\mathrm{AM})$ and indoor air contaminants $\left(\mathrm{CO}, \mathrm{CH}_{2} \mathrm{O}, \mathrm{O}_{3}, \mathrm{PM}_{10}, \mathrm{TVOC}, \mathrm{TBC}, \mathrm{TFC}\right.$, and $\left.\mathrm{CO}_{2}\right)$ were conducted at three points indoor and one point outdoor. The $\mathrm{T}$ and $\mathrm{RH}$ were within the acceptable range of $23-26^{\circ} \mathrm{C}$ and $40-70 \%$, respectively by ICOP, while the AM was very low and less than the acceptable threshold range of $0.15-0.5 \mathrm{~m} / \mathrm{s}$ at $0.08 \mathrm{~m} / \mathrm{s}, 0.04 \mathrm{~m} / \mathrm{s}$, and $0.02 \mathrm{~m} / \mathrm{s}$ at Point 1 , Point 2, and Point 3, respectively. The indoor air contaminants $\left(\mathrm{CO}, \mathrm{CH}_{2} \mathrm{O}, \mathrm{O}_{3}, \mathrm{TVOC}, \mathrm{PM}_{10}\right.$, and TFC) met the standard level of ICOP, except for TBC and $\mathrm{CO}_{2}$. TBC exceeded the ICOP limit $\left(500 \mathrm{cfu} / \mathrm{m}^{3}\right)$ at $1000 \mathrm{cfu} / \mathrm{m}^{3}$ and $1500 \mathrm{cfu} / \mathrm{m}^{3}$, at Point 1 and Point 2, respectively, whereas $\mathrm{CO}_{2}$ concentrations exceeded it $(1000 \mathrm{ppm})$ at $1008.93 \mathrm{ppm}$ at Point 2 . In essence, the results indicated that the ACSU office space with restricted air circulation was inadequately ventilated as the $\mathrm{AM}$ were low, resulting in, high $\mathrm{CO}_{2}$ concentrations and high TBC. Secondly, the indoor air contaminants $\left(\mathrm{CO}, \mathrm{CH}_{2} \mathrm{O}, \mathrm{TVOC}\right.$ and $\left.\mathrm{CO}_{2}\right)$ were higher than those outdoors. The questionnaire survey results reported that the highest present symptom experienced by the workers was drowsiness with $64 \%$. Therefore, it is prudent to ensure the IAQ is within the acceptable limit to avoid any possible health effects on workers within an office space.
\end{abstract}

Keywords: Biological contaminants, chemical air contaminant, specific physical parameter, sustainability, ventilation

Abbreviations: IAQ: Indoor air quality; ACSU: Air conditioning split units; T: Air temperature: RH: Relative humidity; AM: Air movement; $\mathrm{CO}$ : Carbon monoxide; $\mathrm{CH}_{2} \mathrm{O}$ : Formaldehyde; $O_{3}$ : Ozone; $P M_{10}$ : Particulate matter; TVOC: Total volatile organic compound; TBC: Total bacterial count; TFC: Total fungal count; $\mathrm{CO}_{2}$ : Carbon dioxide, ICOP: Industry Code of Practice on Indoor Air Quality 2010

\section{Introduction}

The effect of the indoor environment on people's lives, the performance of work and the public's health is of more concern than the outdoor environment because people spend about $70 \%$ to $90 \%$ of their time in rooms (Yu et al., 2017). The problems with indoor air quality (IAQ) in the office environment in
Malaysia are important risk factors to human health (Lim et al., 2015; Othman et al., 2020). Poor IAQ has been associated with allergies, sick building syndrome (SBS), building-related illnesses (BRI), and acute exposure (de Robles \& Kramer, 2017; Othman et al., 2020). Atarodi et al. (2018) evaluated the symptoms of SBS in an office building in Mashhad, Iran, using the Alberta Indoor Air Quality Tool kit. They 
found that $21 \%$ of the staff viewed the working environment conditions as inappropriate, and they were mostly complaining about the feeling of dusty air, fatigue and headache. Usually, occupants experienced SBS with a series of nonspecific symptoms from being in that building (Thach et al., 2019). Poor IAQ can also affect the respiratory, neurological, reproductive, dermatologic, and cardiovascular systems of the occupants (Azuma et al., 2020).

The analyses of the IAQ took into consideration correlations with the building characteristics (the type of dwelling, the period of construction, dwelling location, type of ventilation system and building material), indoor contaminant sources, outside contaminant sources, maintenance, water intrusion and occupant activity (Prihatmanti \& Bahauddin, 2014; Spiru \& Simona, 2017). Salonen et al., (2018) found that the indoor ozone levels were significantly associated with indoor sources (e.g. printers, photocopiers, and air cleaners), the age of a building, and various housing aspects (carpeting, air conditioning, window fans, and window openings).

Besides that, poor IAQ is often associated with the ventilation within the building. According to Salonen et al. (2018), ventilation is vital in controlling the different indoor air pollutants. Ventilation can influence the type and quantity of chemical compounds (both organic and inorganic) in public buildings, such as in schools and offices (Salonen et al., 2009; Lyng et al., 2015; Vornanen-Winqvist et al., 2018). A study conducted by Rasli et al., (2019) found that sufficient amounts of air were needed to reduce the indoor chemical air contaminants in mosques.

Due to the higher demand for indoor thermal comfort, air-conditioning systems are installed indoors in Malaysian buildings for cooling purposes (Jamaludin et al., 2015). About $50 \%$ of the world's total energy are consumed by buildings (Pérez-Lombard et al., 2008), with a maximum percentage consumed in office buildings (Zhou \& Haghighat, 2009). Thus, it resulted in a higher energy demand and energy cost, which extended the efforts towards building sustainable cities (Jamaludin et al., 2015; Kubota \& Toe, 2015; Kassim et al., 2016; Cui et al., 2017; Laurini et al., 2017). A study by Yau and Hasbi (2017) conducted in an air-conditioned office building in Malaysia found that the cooling load from the use of airconditioning had a negative effect on climate change in the tropical country. The use of airconditioning contributed to poor indoor air quality and reduced the indoor air contaminants removal process as it recirculates the indoor air instead of refreshing it (Spiru \& Simona, 2017; Cui et al., 2017). Therefore, the objective of this assessment is to investigate the indoor air quality comprehensively in a restricted air circulation ACSU office space in accordance to the acceptable limits by ICOP (DOSH, 2010).

\section{Materials and Methods}

\section{Description of the Site Assessment}

The sampling had been carried out in the administrative ACSU office at Universiti Sains Malaysia (USM), Pulau Pinang, which is located at latitude $5^{\circ} 21^{\prime} 20.6^{\prime \prime} \mathrm{N}$ and longitude $100^{\circ} 18$ '16.3'E. A total of 11 workers occupy this office, and the dealing work with video display units/computers, photocopiers, and fax machines, as shown in Figure 1. The work schedule is typically from 8.00 a.m. to 6.00 p.m., but the working time is flexible.

The graph showed that most workers (eight out of eleven) use video display units/computers every day and three out of eleven were using it two to three times weekly. Meanwhile, the workers use the photocopier machines (five out of eleven) every day and six out of eleven use it two to three times weekly. Only three workers use fax machines two to three times weekly.

\section{Workplace Survey (Walkthrough Survey and Questionnaire Form)}

This assessment was started with the walkthrough survey. The walkthrough survey was conducted in the office area to get the necessary insights into the condition of the office area and the 


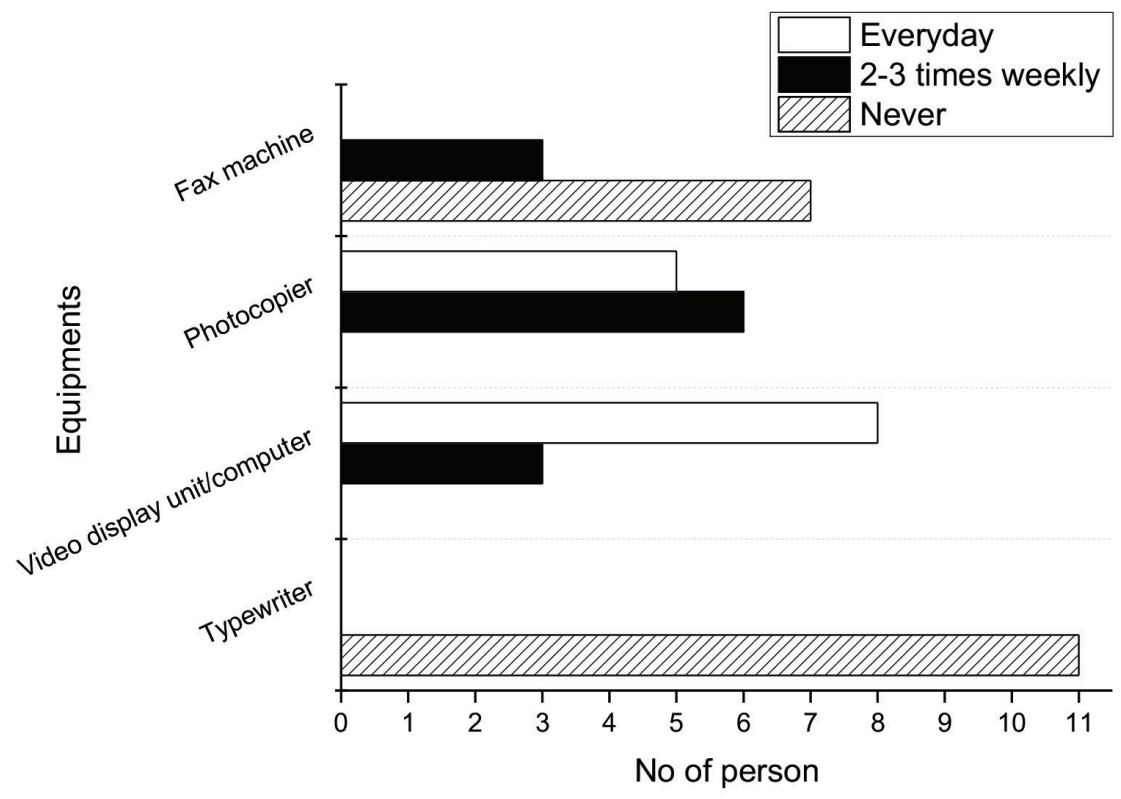

Figure 1: The business activities in the office building

ventilation type (air-conditioning split units (cassette type)). The questionnaires also were distributed to the all workers (11 people) to identify the potential problem and sources of the IAQ and any adverse health effects that may be experienced by the workers. The questionnaire was developed by referring to the Industry Code of Practice on Indoor Air Quality 2010 in Appendix 3 - section B (DOSH, 2010). The questionnaire for building occupants were divided into six (6) sections, and it included general information, background factors, nature of occupation, environmental conditions, past disease/symptoms, and present symptoms. The sample of the questionnaire form is shown in Appendix A.

\section{Assessment of Air-conditioning Split Units}

The office uses five (5) units of cassette type of air-conditioning split units. Each unit has a cooling capacity of $60 \mathrm{HP}$. The indoor unit of the system has four ways of air discharge (supply). Each indoor unit has an area of 1512 $\mathrm{cm}^{2}$ (Length: $54 \mathrm{~cm}$; Width: $7 \mathrm{~cm} \mathrm{x} 4$ outlets) and $3844 \mathrm{~cm}^{2}$ (Length: $62 \mathrm{~cm}$; Width: $62 \mathrm{~cm}$ ) for its air outlet and air inlet, respectively, as shown in Figure 2.
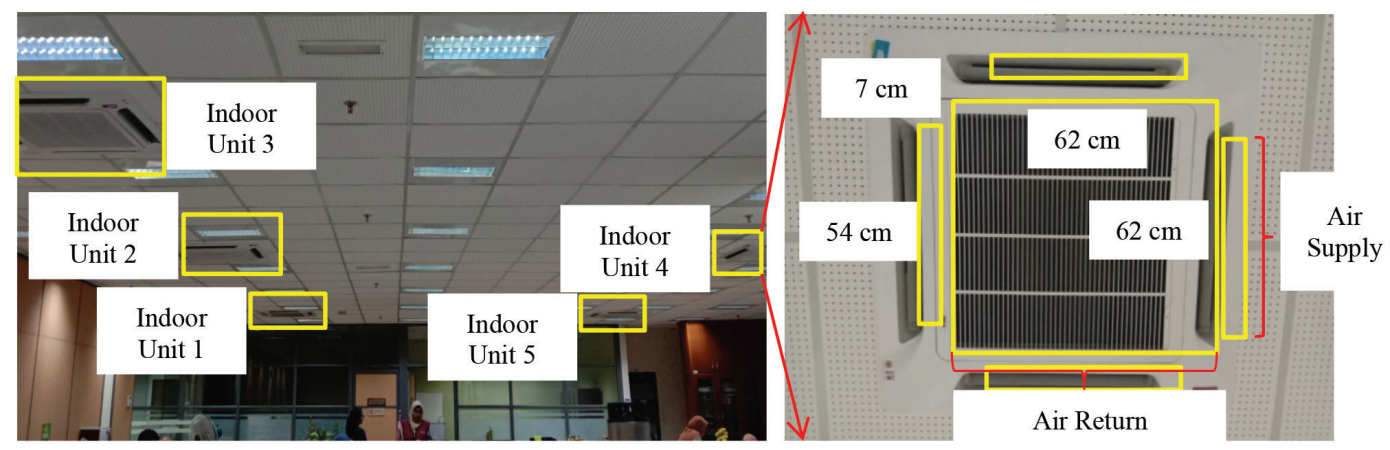

Figure 2: The location and size of each air inlet and outlet 


\section{Air Sampling and Instrumentation}

\section{Selection of Monitoring Instruments}

An Indoor Air Quality probe (IQ-610) was used to measure the levels of carbon monoxide (CO), the total volatile organic compound (TVOC), ozone $\left(\mathrm{O}_{3}\right)$, carbon dioxide $\left(\mathrm{CO}_{2}\right)$, air temperature $(\mathrm{T})$ and relative humidity $(\mathrm{RH})$, whereas the level of formaldehyde $\left(\mathrm{CH}_{2} \mathrm{O}\right)$ was monitored using the Formaldehyde Multi-Mode Monitor (FM-801). The AS-201 was used to measure air movement (AM). The instruments used were the GrayWolf Model. Besides that, the Airborne Particle Counter (Handheld 3016 IAQ) Light House Model was used for particulate matter $\left(\mathrm{PM}_{10}\right)$. Moreover, the total bacterial count (TBC) and total fungal count (TFC) were sampled using a microbial air sampler (MAS100 Model ECO).

The quality assurance and quality control (QA/QC) for the GrayWolf Model, Lighthouse Model, and ECO model were performed using the annual factory calibration. All instruments were attached on a tripod, and the output parameters were displayed on a setup screen. The parameters reading were obtained after 30 minutes to one hour for stabilisation. Then, the location was set according to the current time and date of monitoring. The data were set to oneminute real-time average (100\% data logging). The selected sampling points were at least 0.5 $\mathrm{m}$ from the walls, corners and windows, but not directly in front of the air-conditioning system units and floor fans; and not within $2 \mathrm{~m}$ of the doors.

\section{Sampling Strategy}

A total of three sampling points indoors were selected for the IAQ assessment, as shown in Figure 3. The office has an area of 134.022 $\mathrm{m}^{2}$ and a volume of $367.086 \mathrm{~m}^{3}$. The chosen points represented the whole floor area of the office and based on the primary workstation, work activities, and the highest occupancy. This assessment was conducted by taking a realtime measurement intermittently (four slots of 30 minutes each) for nine hours from 8.00 a.m. until 6.00 p.m. at three sampling points within the office area; and one sampling point outdoors for 30 minutes.

For the biological (TBC and TFC) samplings, the air samples were collected to measure the total count for both parameters in colony-forming unit per cubic meter of air (cfu/ $\mathrm{m}^{3}$ ) within the office area. A microbial air sampler (100 Model Eco Pump, Merck, and Darmstadt, Germany) was used for all collections; it has a flow rate of $100 \mathrm{~L} / \mathrm{min}$, and a sampling time of five minutes to avoid the accumulation of unaccountable microorganisms. The airborne microorganisms were targeted one after another using a $20 \mathrm{~mL}$ nutrient plate of Tryptic Soy Agar (TSA) for bacteria, and Sabouraud Dextrose Agar with Chloramphenicol (SDAC) for fungi, which was coupled inside the stage sampler at the three sampling points. The Petri plates had been prepared according to the sampler manufacturer's recommendations for both bacteria and fungi by referring to the National Institute for Occupational Safety and Health (NIOSH) Method 0800 - Bioaerosol Sampling of Indoor Air by the National Institute for Occupational Safety and Health (NIOSH, 1998). When changing the collection plates, the stage hole was sterilised with a $70 \%$ ethanol solution to prevent cross-contamination. The collected samples were kept in a cool box. After sample collection, the agar plates were transported to the laboratory and incubated at $35 \pm 1{ }^{\circ} \mathrm{C}$ for 24 hours for bacteria and at $25 \pm 1{ }^{\circ} \mathrm{C}$ for five days for fungi (Park et al., 2013). 


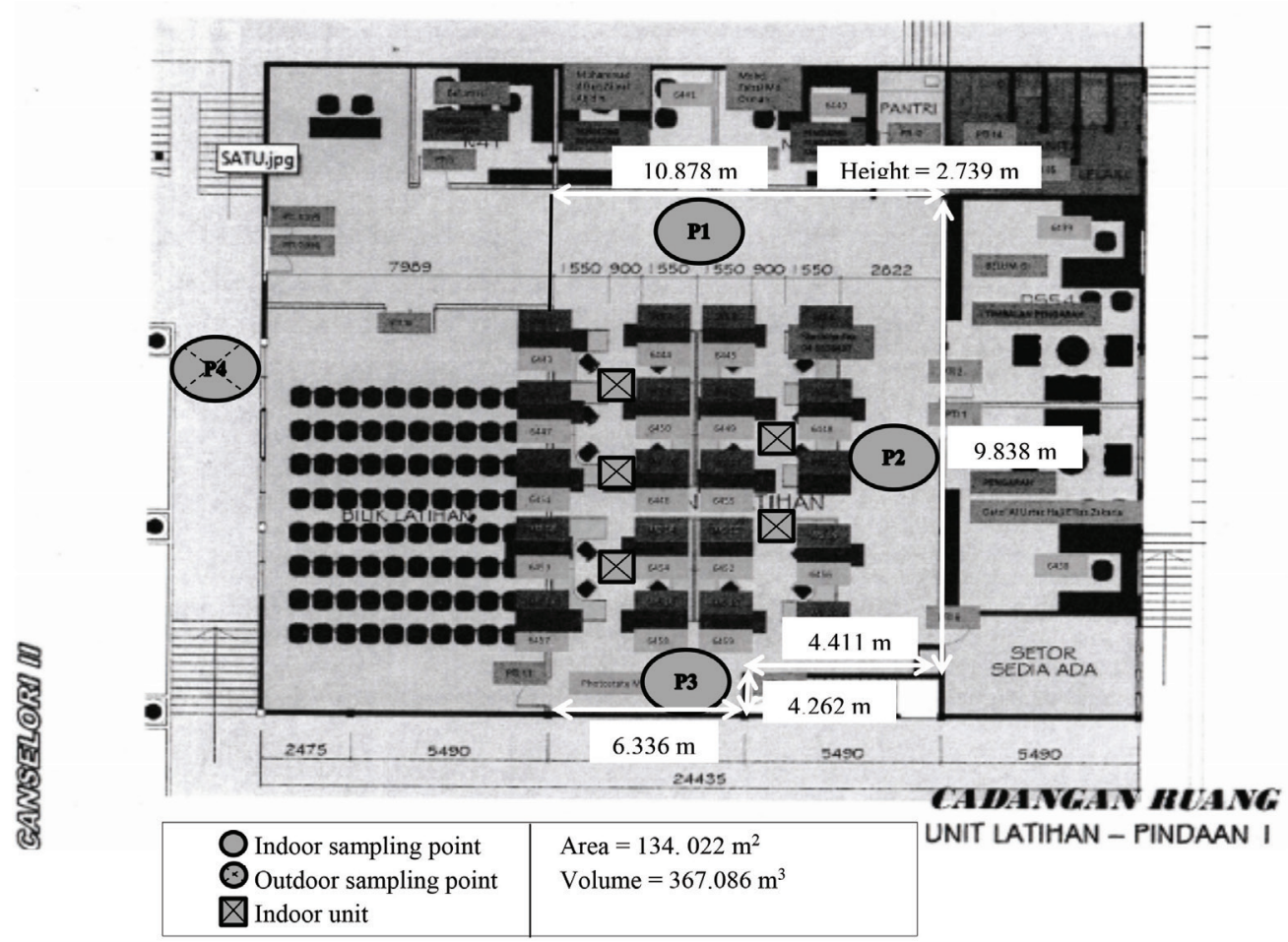

Figure 3: The layout of the sampling points and the dimensions of each sampling points at the administrative office

\section{Results and Discussion}

\section{Specific Physical Parameters}

Table 1 shows the descriptive statistic of specific physical parameters following the Industry Code of Practice (ICOP) limits (DOSH, 2010). The results obtained suggested that the $\mathrm{T}$ and RH at Point 1, Point 2, and Point 3 were within the acceptable range of $23-26^{\circ} \mathrm{C}$ and $40-70 \%$, respectively. The $\mathrm{T}$ recorded were $22.64^{\circ} \mathrm{C}$, $23.14^{\circ} \mathrm{C}$, and $24.69^{\circ} \mathrm{C}$ at Point 1 , Point 2 , and Point 3, respectively, whereas the RH were $54.50 \%, 52.73 \%$, and $51.06 \%$, respectively. However, the AM at Point $1(0.08 \mathrm{~m} / \mathrm{s})$, Point $2(0.04 \mathrm{~m} / \mathrm{s})$, and Point $3(0.02 \mathrm{~m} / \mathrm{s})$ were less than the acceptable range $(0.15-0.5 \mathrm{~m} / \mathrm{s})$ as recommended by ICOP. The results indicated that the office area could be considered as inadequately ventilated. The office area has restricted air circulation as the split unit airconditioning systems (cassette type) have no built-in provisions for ventilation. This resulted in notable increases in indoor air contaminant levels (Al-Awadi, 2018). Elbayoumi et al. (2015) found that air movement is very significant for indoor air circulation (wind) inside the building. Higher air movements can improve thermal comfort with a pleasant internal sensation (Chow et al., 2010).

\section{Indoor Air Contaminants}

The indoor air contaminants were divided into the chemical contaminants $\left(\mathrm{CO}, \mathrm{CH}_{2} \mathrm{O}, \mathrm{O}_{3}\right.$, $\mathrm{PM}_{10}$, and TVOC), biological contaminants (TBC and TFC), and ventilation performance indicator $\left(\mathrm{CO}_{2}\right)$. Table 2 shows the descriptive statistic of indoor air contaminants following the ICOP limit standards. The results showed that all the chemical air contaminants $(\mathrm{CO}$, $\mathrm{CH}_{2} \mathrm{O}, \mathrm{O}_{3}, \mathrm{PM}_{10}$, and TVOC) at Point 1, Point 2 , and Point 3 were within the acceptable limits as recommended by ICOP. However, for biological contaminants, the TBC at Point 1 
Table 1: Descriptive statistics of specific physical parameters following ICOP limits

\begin{tabular}{ccccccc}
\hline Parameter & $\begin{array}{c}\text { Descriptive } \\
\text { Statistical }\end{array}$ & Point 1 & Point 2 & Point 3 & $\begin{array}{c}\text { ICOP } \\
\text { Limit }\end{array}$ & Unit \\
\hline \multirow{4}{*}{ a. T } & N & 120 & 120 & 120 & & \\
& Mean & 22.64 & 23.14 & 24.69 & & \\
& Std. Dev. & 0.25 & 0.32 & 0.28 & $23-26$ & ${ }^{\circ} \mathrm{C}$ \\
& Min. & 21.9 & 22.4 & 24.1 & & \\
& Max. & 23.2 & 23.8 & 25.3 & & \\
b. RH & N & 120 & 120 & 120 & & \\
& Mean & 54.50 & 52.73 & 51.06 & & \\
& Std. Dev. & 1.89 & 1.65 & 1.61 & $40-70$ & \\
& Min. & 50.5 & 50.2 & 48.1 & & \\
& Max. & 58.9 & 55.8 & 54.3 & & \\
& N & 120 & 120 & 120 & & \\
& Mean & 0.08 & 0.04 & 0.02 & & \\
\hline & Std. Dev. AM & 0.04 & 0.02 & 0.02 & $0.15-0.5$ & \\
& Min. & 0.02 & 0.01 & 0.01 & & \\
& Max. & 0.22 & 0.12 & 0.12 & & \\
& & & & & \\
\hline
\end{tabular}

and Point 2 exceeded the acceptable ICOP limit $\left(500 \mathrm{cfu} / \mathrm{m}^{3}\right)$ at $1000 \mathrm{cfu} / \mathrm{m}^{3}$ and $1500 \mathrm{cfu} / \mathrm{m}^{3}$, respectively. Meanwhile, the total fungal counts at Point 1 , Point 2, and Point 3 were within the recommended limit of $1000 \mathrm{cfu} / \mathrm{m}^{3}$.

The TBC was high as it exceeded up to two times the acceptable limit $\left(500 \mathrm{cfu} / \mathrm{m}^{3}\right)$ for indoor air at Point $1\left(1000 \mathrm{cfu} / \mathrm{m}^{3}\right)$, and three times at Point $3\left(1500 \mathrm{cfu} / \mathrm{m}^{3}\right)$. The higher total bacterial count in the office space could be influenced by temperature, relative humidity, the building itself (including ventilation strategies, moisture levels, and building materials), and the air-conditioning system. There were many other factors that contributed to the high concentrations of biological contaminants, including a higher level of occupancy and activity, such as breathing, sweating, and movements causing secondary dust lifting, as well as the air distribution system, water damage ventilation problems, poor lighting, and poor housekeeping (Adams et al., 2016; NIOSH, 2016; Basińska et al., 2019; Rasli et al., 2019). Hameed and Habeeballah (2013) found that high concentrations of biological pollutants have been found in mosques in the Kingdom of Saudi Arabia due to the low ventilation rates.

Also, moisture problems in air-conditioned buildings, also known broadly as "dampness" could contribute to the most consistent risk factors for health problems, air quality, and atmospheric dynamics (Mendell et al., 2011; Kanchongkittiphon et al., 2015; Li et al., 2015; Xie et al., 2018; Gong et al., 2020). A previous study by Rasli et al. (2019) also found that the total bacterial count and total fungal count were higher in ACSU Malaysian mosques compared with non-ACSU mosques. The airborne disease infection across the built environment can be spread by bacteria and virus (Li et al., 2019). A study by Zock et al., (2002) on dampness at home found that indoor microbe growth had a negative impact on adult asthma. The air relative humidity, either intentionally or unintentionally, is sufficient to support microbial growth (Adams et al., 2016). Tang et al., (2019) found that the relative humidity of $65 \%$ to $75 \%$ in inpatient buildings during summer influenced the microbial growth on indoor surfaces. 
Table 2: Descriptive statistics of indoor air contaminants following ICOP limit standards

\begin{tabular}{|c|c|c|c|c|c|c|}
\hline $\begin{array}{c}\text { Indoor air } \\
\text { Contaminants }\end{array}$ & $\begin{array}{l}\text { Descriptive } \\
\text { Statistical }\end{array}$ & Point 1 & Point 2 & Point 3 & $\begin{array}{l}\text { ICOP } \\
\text { Limit }\end{array}$ & Unit \\
\hline & \multicolumn{6}{|c|}{ Chemical contaminants } \\
\hline \multirow{5}{*}{$\mathrm{CO}$} & $\mathrm{N}$ & 120 & 120 & 120 & \multirow{5}{*}{10} & \multirow{5}{*}{ Ppm } \\
\hline & Mean & 1.33 & 1.64 & 1.64 & & \\
\hline & Std. Dev. & 0.45 & 0.47 & 0.31 & & \\
\hline & Min. & 0.6 & 1.1 & 1.1 & & \\
\hline & Max. & 2.2 & 2.4 & 2.3 & & \\
\hline \multirow{5}{*}{$\mathrm{CH}_{2} \mathrm{O}$} & $\mathrm{N}$ & 120 & 120 & 120 & \multirow{5}{*}{0.1} & \multirow{5}{*}{ Ppm } \\
\hline & Mean & 0.011 & 0.021 & 0.014 & & \\
\hline & Std. Dev. & 0.008 & 0.006 & 0.007 & & \\
\hline & Min. & 0.011 & 0.012 & 0.011 & & \\
\hline & Max. & 0.031 & 0.032 & 0.033 & & \\
\hline \multirow{5}{*}{$\mathrm{O}_{3}$} & $\mathrm{~N}$ & 120 & 120 & 120 & \multirow{5}{*}{0.05} & \multirow{5}{*}{ Ppm } \\
\hline & Mean & 0.00 & 0.00 & 0.00 & & \\
\hline & Std. Dev. & 0.00 & 0.00 & 0.00 & & \\
\hline & Min. & 0.00 & 0.00 & 0.00 & & \\
\hline & Max. & 0.00 & 0.00 & 0.00 & & \\
\hline \multirow{5}{*}{$\mathrm{PM}_{10}$} & $\mathrm{~N}$ & 120 & 120 & 120 & \multirow{5}{*}{0.15} & \multirow{5}{*}{$\mathrm{mg} / \mathrm{m}^{3}$} \\
\hline & Mean & 0.023 & 0.023 & 0.011 & & \\
\hline & Std. Dev. & 0.017 & 0.015 & 0.002 & & \\
\hline & Min. & 0.008 & 0.008 & 0.008 & & \\
\hline & Max. & 0.060 & 0.056 & 0.015 & & \\
\hline \multirow{5}{*}{ TVOC } & $\mathrm{N}$ & 120 & 120 & 120 & \multirow{5}{*}{3} & \multirow{5}{*}{ Ppm } \\
\hline & Mean & 0.706 & 0.721 & 0.673 & & \\
\hline & Std. Dev. & 0.068 & 0.075 & 0.045 & & \\
\hline & Min. & 0.606 & 0.634 & 0.589 & & \\
\hline & Max. & 0.862 & 0.856 & 0.735 & & \\
\hline & \multicolumn{6}{|c|}{ Biological contaminants } \\
\hline \multirow{2}{*}{$\mathrm{TBC}$} & $\mathrm{N}$ & 3 & 3 & 3 & \multirow{2}{*}{500} & \multirow{2}{*}{$\mathrm{cfu} / \mathrm{m}^{3}$} \\
\hline & Count & 1000 & 1500 & 170 & & \\
\hline \multirow{2}{*}{ TFC } & $\mathrm{N}$ & 3 & 3 & 3 & \multirow{2}{*}{1000} & \multirow{2}{*}{$\mathrm{cfu} / \mathrm{m}^{3}$} \\
\hline & Count & 200 & 170 & 170 & & \\
\hline & \multicolumn{6}{|c|}{ Ventilation performance indicators } \\
\hline \multirow{5}{*}{$\mathrm{CO}_{2}$} & $\mathrm{~N}$ & 120 & 120 & 120 & \multirow{5}{*}{$\mathrm{C} 1000$} & \multirow{5}{*}{ Ppm } \\
\hline & Mean & 995.83 & 1008.93 & 916.53 & & \\
\hline & Std. Dev. & 116.90 & 86.26 & 57.19 & & \\
\hline & Min. & 664.00 & 761.00 & 711.00 & & \\
\hline & Max. & 1042.00 & 1039.00 & 941.00 & & \\
\hline
\end{tabular}


For ventilation performance indicator, the $\mathrm{CO}_{2}$ concentrations at Point 1 (995.83 ppm) and Point 3 (916.53 ppm) were within the acceptable limits of $1000 \mathrm{ppm}$ as recommended by ICOP (DOSH, 2010), except for Point 2 (1008.93 ppm). Although the $\mathrm{CO}_{2}$ levels at Point 1 (995.83 ppm) and Point 3 (916.53ppm) did not exceed the limits, they were approaching the acceptable limit. The high $\mathrm{CO}_{2}$ concentrations recorded in the office space show that the office space was inadequately ventilated in the restricted air circulation of the ACSU office building as the air movements recorded was low and could perhapse provide the conditions for bacterial growth. The $\mathrm{CO}_{2}$ concentration in indoor air indicates ventilation rate, comfort status, indoor air quality, high occupancy rate and pollution levels (Godwin \& Batterman, 2007; Mahayuddin \& Awbi, 2012; Batog \& Badura, 2013; McGill et al., 2015; Fan et al., 2017; Hussin, 2017; Al-Awadi, 2018). Thus, the high $\mathrm{CO}_{2}$ concentrations level in the office space reflected the lack of ventilation, poor air quality, and the indoor air is not refreshed enough within the office building. An office space should have adequate air exchange in addition to cooling. Recirculating $100 \%$ of the indoor air, and having no fresh air entrainment would not be healthy for occupants of the office buildings (Al-Awadi, 2018). The studies by Ocak et al. (2012) and Rasli et al., (2019) also found that inadequate ventilation rates, high number of occupants, and their activities contributed to high $\mathrm{CO}_{2}$ concentrations in mosque buildings. Besides that, the high $\mathrm{CO}_{2}$ level within the office area might have an effect on human metabolism as the exhale rate for light work is $0.3 \mathrm{~L} / \mathrm{min}$ (Mahayuddin and Awbi, 2012; NIOSH, 2016). At relatively low concentration $(<3 \%), \mathrm{CO}_{2}$ can cause headaches, increase in pulse rates, uncharacteristically high fatigue and breathing difficultness. High levels of $\mathrm{CO}$ and $\mathrm{CO}_{2}$ can contribute to nausea, dizziness, vomiting, and loss of consciousness (NIOSH, 2016).

For the outdoor sampling at Point 4, the results show that there were no potential severe sources from outdoors as the chemical air contaminants $\left(\mathrm{CO}, \mathrm{CH}_{2} \mathrm{O}, \mathrm{PM}_{10}, \mathrm{O}_{3}\right.$, and TVOC) and ventilation performance indicator $\left(\mathrm{CO}_{2}\right)$ did not exceed the acceptable limits set by ICOP (DOSH, 2010) as shown in Table 3. Indeed, some of the indoor chemical contaminants $(\mathrm{CO}$, $\mathrm{CH}_{2} \mathrm{O}$ and TVOC) and ventilation performance indicator $\left(\mathrm{CO}_{2}\right)$ were higher than the outdoor air contaminants. The high indoor air contaminants compared to outdoors may indicate that the sources came from the indoor space itself. The sources of $\mathrm{CO}$ concentration may have come from the heater in the nearby pantry; the $\mathrm{CH}_{2} \mathrm{O}$ may have come from the building materials, the TVOC may have come from building materials and furnishings, and $\mathrm{CO}_{2}$ may have comes from human metabolism, from breathing. Growing scientific evidence during the last few decades has indicated that the concentrations of certain pollutants in indoor air maybe 2 to 5 times, and occasionally more than 100 times higher, than those in outdoor air (USEPA, 2017; Zock et al., 2002).

Table 3: The air contaminants and specific physical parameters outdoors

\begin{tabular}{ccccc}
\hline $\begin{array}{c}\text { Indoor air } \\
\text { Contaminants }\end{array}$ & $\begin{array}{c}\text { Descriptive } \\
\text { Statistical }\end{array}$ & $\begin{array}{c}\text { Point 4 } \\
\text { (Outdoor) }\end{array}$ & ICOP & Unit \\
\hline \multicolumn{4}{c}{ Chemical contaminants } & \\
$\mathrm{N}$ & 30 & & \\
$\mathrm{CO}$ & Mean & 1.00 & 10 & Ppm \\
& Std. Dev. & 0.19 & & \\
& Min. & 0.70 & & \\
& Max. & 1.30 & & \\
\hline
\end{tabular}




\begin{tabular}{|c|c|c|c|c|}
\hline \multirow{5}{*}{$\mathrm{CH}_{2} \mathrm{O}$} & $\mathrm{N}$ & 30 & \multirow{5}{*}{0.1} & \multirow{5}{*}{ Ppm } \\
\hline & Mean & 0.014 & & \\
\hline & Std. Dev. & 0.003 & & \\
\hline & Min. & 0.011 & & \\
\hline & Max. & 0.020 & & \\
\hline \multirow{5}{*}{$\mathrm{O}_{3}$} & $\mathrm{~N}$ & 30 & & \multirow{5}{*}{ Ppm } \\
\hline & Mean & 0.03 & 0.05 & \\
\hline & Std. Dev. & 0.01 & & \\
\hline & Min. & 0.02 & & \\
\hline & Max. & 0.05 & & \\
\hline \multirow{5}{*}{$\mathrm{PM}_{10}$} & $\mathrm{~N}$ & 30 & \multirow{5}{*}{0.15} & \multirow{5}{*}{$\mathrm{mg} / \mathrm{m}$} \\
\hline & Mean & 0.027 & & \\
\hline & Std. Dev. & 0.23 & & \\
\hline & Min. & 0.026 & & \\
\hline & Max. & 0.027 & & \\
\hline \multirow{5}{*}{ TVOC } & $\mathrm{N}$ & 30 & \multirow{5}{*}{3} & \multirow{5}{*}{ Ppm } \\
\hline & Mean & 0.392 & & \\
\hline & Std. Dev. & 0.015 & & \\
\hline & Min. & 0.357 & & \\
\hline & Max. & 0.421 & & \\
\hline
\end{tabular}

\section{Ventilation performance indicators}

\begin{tabular}{|c|c|c|c|c|}
\hline \multirow{5}{*}{$\mathrm{CO}_{2}$} & $\mathrm{~N}$ & 30 & \multirow{5}{*}{$\mathrm{C} 1000$} & \multirow{5}{*}{ Ppm } \\
\hline & Mean & 505.17 & & \\
\hline & Std. Dev. & 30.99 & & \\
\hline & Min. & 444.00 & & \\
\hline & Max. & 556.00 & & \\
\hline \multicolumn{5}{|c|}{ Specific physical parameters } \\
\hline \multirow{5}{*}{$\mathrm{T}$} & $\mathrm{N}$ & 30 & \multirow{5}{*}{$23-26$} & \multirow{5}{*}{${ }^{\circ} \mathrm{C}$} \\
\hline & Mean & 32.38 & & \\
\hline & Std. Dev. & 0.31 & & \\
\hline & Min. & 31.80 & & \\
\hline & Max. & 32.90 & & \\
\hline \multirow{5}{*}{$\mathrm{RH}$} & $\mathrm{N}$ & 30 & \multirow{5}{*}{$40-70$} & \multirow{5}{*}{$\%$} \\
\hline & Mean & 49.45 & & \\
\hline & Std. Dev. & 1.35 & & \\
\hline & Min. & 47.50 & & \\
\hline & Max. & 52.90 & & \\
\hline
\end{tabular}


Therefore, the indoor air quality in the office building needs to be monitored as it is an essential factor in maintaining employee productivity and health (Kubba, 2009; Hussin 2017). Vasile et al. (2016) suggested increasing the airtightness of the building envelope by analysing and making use of the natural ventilation system. Rasli et al. 2019 suggested inducing optimum air movement through pores for better ventilation. Batog and Badura (2013) also recommended applying proper air vents near airtight windows. Besides that, it is recommended to use only small air streams that can improve $\mathrm{CO}_{2}$ and dust concentrations to lower the total bacterial count in the office building (Basińska et al., 2019). Besides, it is recommended to reduce the relative humidity levels through ventilation strategies as it could potentially reduce the proliferation of microbes, but not below than $30 \%$ as it may cause sensory irritation (McGill et al., 2015). The building owner or building management needs to ensure to remove the excess water and make the necessary repairs to prevent further microbe accumulation (DOSH, 2010).

Thus, the results obtained could indicate that indoor air contaminants can originate from a range of sources. The possible sources of indoor air contaminants may arise from a variety of sources, including the fabric of buildings, the occupants' activities, biological sources, the combustion of substances for heating or fuel, emission from building materials, and it can also be a byproduct of activities within the buildings (Azuma et al., 2020).

\section{Health Complaints (Signs and Symptoms Related to Indoor Air Quality Problem)}

The results from the questionnaire forms in Figure 4 shows the factors that had bothered the workers during the last three months at the workstation. The workers sometimes experienced varying room temperature (eight persons), room temperature that is too high (six persons), room temperature that is too low (five persons), stuffy "bad" air (four persons), unpleasant odour (three persons), draught (two persons), and one vote each for dust and dirt, passive smoking, and dry air. Meanwhile, Figure 5 shows the past symptoms of diseases. Based on the questionnaires, there was only one person who experienced eczema, two experienced sinusitis and one had asthmatic problems.

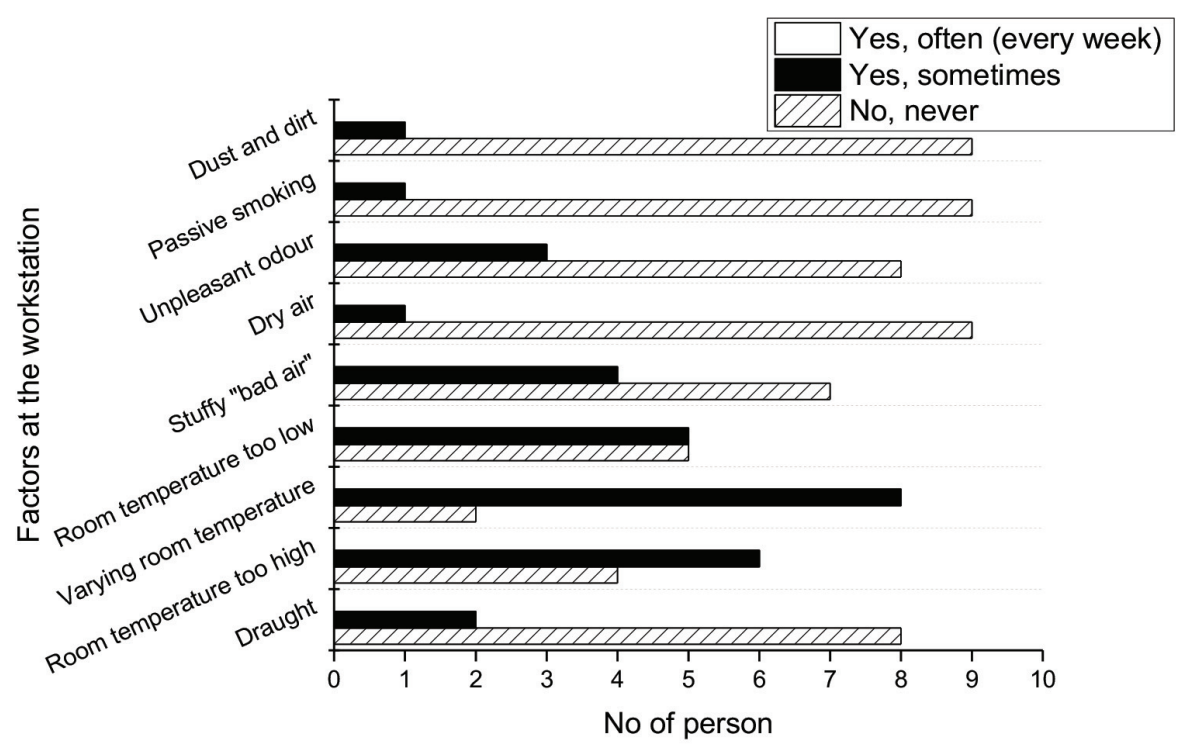

Figure 4: Factors that had bothered the workers during the last three (3) months at the workstation 


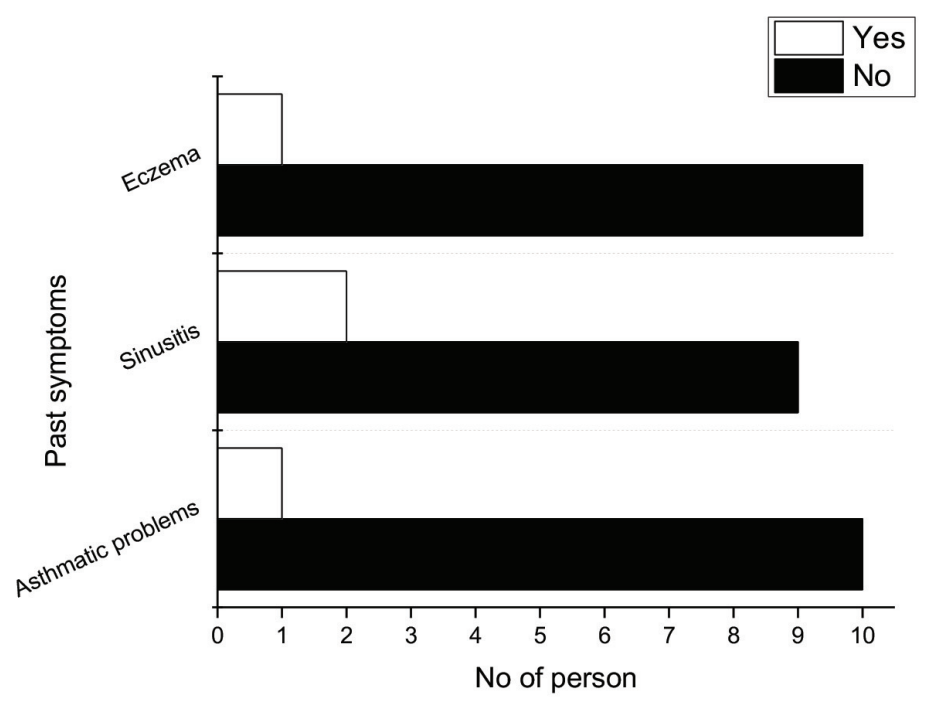

Figure 5: The past symptoms of diseases

Figure 6 shows the present symptoms of diseases during the last three months at the workstation. The symptoms, such as headaches, fatigue/lethargy, drowsiness, and irritated stuffy nose, were experienced by the workers often (every week), but only voted by one person for each. Health-related symptoms experienced by the workers sometimes (two to three times/ week), in descending order, were drowsiness (seven people), headache, heavy-headedness, and fatigue/lethargy (voted by five people each), dizziness, cough, irritated and stuffy nose, hoarse/dry throat, and irritation of the eyes (voted by three people each), whereas skin rash/ itchiness and scaling/itching scalp was voted by one person each.

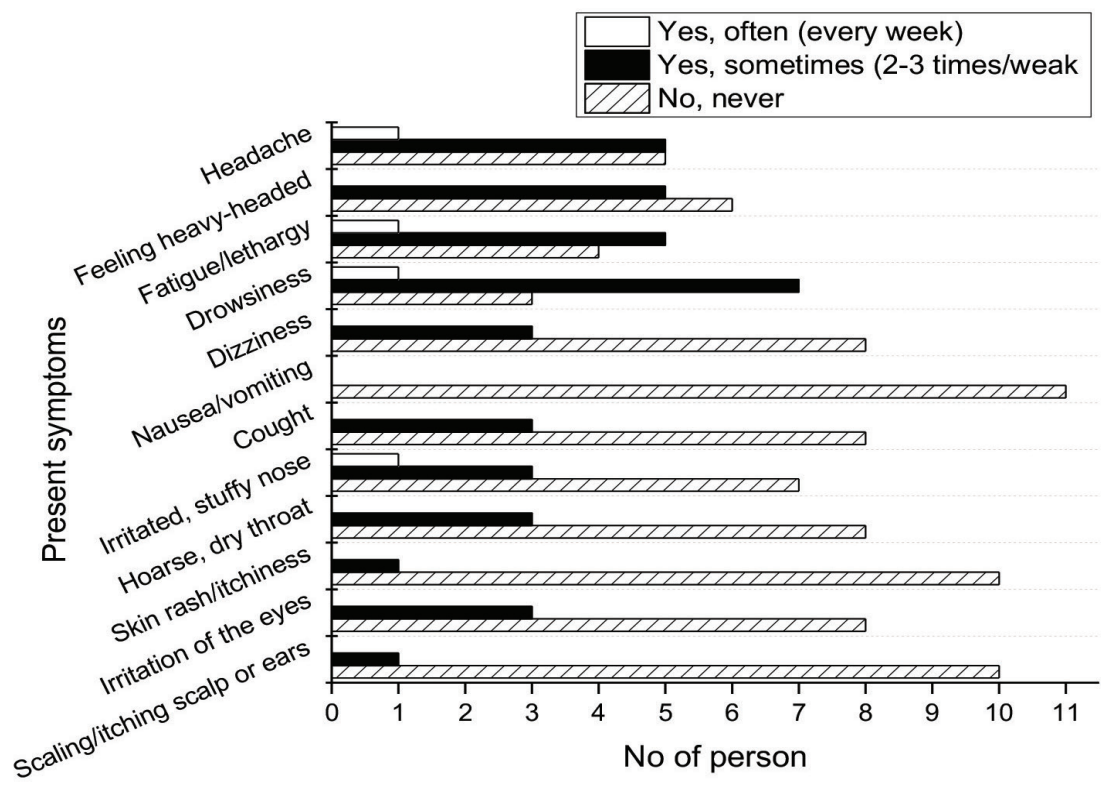

Figure 6: The present symptoms of diseases during the last three (3) months at the workstation 
Besides, based on questionnaires, the highest $(73 \%)$ factor that had bothered the workers during the last three months at the workstation was varying room temperature. This could be because the air could not be equally distributed within the office building, and the ACSU needed to be checked for maintainance. The past symptoms experienced by the workers were eczema, sinusitis, and asthmatic problems at $9 \%, 18 \%$, and $9 \%$, respectively, whereas the highest present symptoms were drowsiness at $64 \%$. Even though there were some inadequacies in the physical results of the IAQ, the symptoms of illnesses among the space occupants are still low. Care should be taken as inadequate ventilation in the office building caused the risk of SBS and BRI, which can affect the comfort and the health of the occupants (Vasile et al., 2016; Kubba, 2009).

\section{Conclusions}

The workers usually spend eight hours in the ACSU office space with restricted air circulation. Therefore, this assessment aims to investigate the indoor air quality comprehensively in the restricted air circulation of an ACSU office space in accordance to acceptable limit by ICOP. An IAQ assessment was initalised with a walkthrough survey, followed by the filling of questionnaires for fundamental insights (i.e. general information of the office building, background factor of the occupant, nature of occupation, environmental condition, past disease/symptoms, and present symptoms) into the office operations. Then, the assessment was continued by monitoring the specific physical parameters (i.e. T, RH, and $\mathrm{AM}$ ) and indoor air contaminants, which included chemical contaminants $\left(\mathrm{CO}, \mathrm{CH}_{2} \mathrm{O}, \mathrm{O}_{3}, \mathrm{PM}_{10}\right.$, and TVOC), biological contaminants (TBC and TFC), and ventilation performance indicator $\left(\mathrm{CO}_{2}\right)$ at three points indoors and one point outdoors. For specific physical parameters, the results showed that the $\mathrm{T}$ at Point $1\left(22.64{ }^{\circ} \mathrm{C}\right)$, Point $2\left(23.14{ }^{\circ} \mathrm{C}\right)$, and Point $3\left(24.69^{\circ} \mathrm{C}\right)$ and $\mathrm{RH}$ at Point 1 (54.50\%), Point 2 (52.73\%), and Point $3(51.06 \%)$ were within the acceptable range $\left(23-26{ }^{\circ} \mathrm{C}\right)$ and $(40-70 \%)$ according to ICOP, whereas the AM $(0.15-0.5 \mathrm{~m} / \mathrm{s})$ did not. The air movements recorded at Point 1, Point 2, and Point 3 were $0.08 \mathrm{~m} / \mathrm{s}, 0.04 \mathrm{~m} / \mathrm{s}$, and 0.02 $\mathrm{m} / \mathrm{s}$, respectively. For indoor air contaminants $\left(\mathrm{CO}, \mathrm{CH}_{2} \mathrm{O}, \mathrm{PM}_{10}, \mathrm{TVOC}, \mathrm{O}_{3}\right.$, and TFC), they were within the acceptable limits by ICOP, except for $\mathrm{CO}_{2}$ at Point 1 and TBC at Points 1 and 2. The $\mathrm{CO}_{2}$ concentrations exceeded the ICOP limit of $1000 \mathrm{ppm}$ at $1008.93 \mathrm{ppm}$. Meanwhile, TBC exceeded the ICOP limit (500 $\left.\mathrm{cfu} / \mathrm{m}^{3}\right)$ at two times over the limit $(1000 \mathrm{cfu} /$ $\left.\mathrm{m}^{3}\right)$ and three times over the limit $\left(1500 \mathrm{cfu} / \mathrm{m}^{3}\right)$ at Point 1and Point 2, respectively. The office area has an improper ventilation or deficiencies in the ventilation system, which contributes to the poor air distribution within the office area. The lower AM recorded resulted in the high $\mathrm{CO}_{2}$ concentrations and high TBC within the office space. Besides, this study also found that the indoor chemical contaminants $(\mathrm{CO}$, $\mathrm{CH}_{2} \mathrm{O}$ and TVOC) and ventilation performance indicator $\left(\mathrm{CO}_{2}\right)$ recorded within the office area were higher than the outdoor air contaminants. It may indicate that the sources of indoor air contaminants originated indoors. Besides, based on the questionnaire survey analysis, the highest present symptom experienced by the workers was drowsiness at $64 \%$. Even though there are element of adequacies in the physical results of the IAQ, the symptoms of illnesses among the space occupants are low. Therefore, the air movement needs to be ensured in the recommended range to aid in lowering the $\mathrm{CO}_{2}$ concentrations and control of microbial growth to avert any possible health effects on workers within the office buildings. Some fresh air also needed to be introduced into the ACSU office building, which has restricted air circulation, for a better IAQ.

\section{Acknowledgements}

This research was supported by Universiti Sains Malaysia under the USM Bridging Grant (304/ PAWAM/6316537) and Unit Keselamatan dan Kesihatan Pekerjaan (UKKP). 


\section{References}

Adams, R. I., Bhangar, S., Dannemiller, K. C., Eisen, J. A., Fierer, N., Gilbert, J. A., Green, J. L., Marr, L. C., Miller, S. L., Siegel, J. A., \& Stephens, B. (2016). Ten questions concerning the microbiomes of buildings. Building and Environment, 109, 224-234.

Al-Awadi, L. (2018). Assessment of indoor levels of volatile organic compounds and carbon dioxide in schools in Kuwait. Journal of the Air \& Waste Management Association, 68(1), 54-72.

Atarodi, Z., Karimyan, K., Gupta, V. K., Abbasi, M., \& Moradi, M. (2018). Evaluation of indoor air quality and its symptoms in office building-A case study of Mashhad, Iran. Data in Brief, 20, 74-79.

Azuma, K., Jinno, H., Tanaka-Kagawa, T., \& Sakai, S. (2020). Risk assessment concepts and approaches for indoor air chemicals in Japan. International Journal of Hygiene and Environmental Health, 225, 1-9.

Basińska, M., Michałkiewicz, M., \& Ratajczak, K. (2019). Impact of physical and microbiological parameters on proper indoor air quality in a nursery. Environment International, 132, 1-14.

Batog, P., \& Badura, M. (2013). Dynamic of changes in carbon dioxide concentration in bedrooms. Procedia Engineering, 57, 175182.

Chow, T. T., Fong, K. F., Givoni, B., Lin, Z., \& Chan, A. L. S. (2010). The thermal sensation of Hong Kong people with increased airspeed, temperature and humidity in an air-conditioned environment. Building and Environment, 45(10), 2177-2183.

Cui, X., Mohan, B., Islam, M. R., Chou, S. K., \& Chua, K. J. (2017). Energy-saving potential of an air treatment system for improved building indoor air quality in Singapore. Energy Procedia, 143, 283-288.

de Robles, D., \& Kramer, S. W. (2017). Improving indoor air quality through the use of ultraviolet technology in commercial buildings. Procedia Engineering, 196, 888894.

DOSH. (2010). Department of Occupational Safety and Health. Industry code of practice on indoor air quality. Malaysia: Ministry of Human Resources, 1-39.

Elbayoumi, M., Ramli, N. A., \& Md Yusof, N. F. F. (2015). Spatial and temporal variations in particulate matter concentrations in twelve schools environment in urban and overpopulated camps landscape. Building and Environment, 90, 157-167.

Fan, G., Xie, J., \& Liu, J. (2017). Indoor air quality in a naturally ventilated research student office in Chinese universities during the heating period. Procedia Engineering, 205, 1272-1278.

Godwin, C., \& Batterman, S. (2007). Indoor air quality in Michigan schools. Indoor Air, 17, 109-121.

Gong, J., Qi, J., Beibei, E., Yin, Y., \& Gao, D. (2020). Concentration, viability and size distribution of bacteria in atmospheric bioaerosols under different types of pollution. Environmental Pollution, 257, $1-11$.

Hameed, A. A., \& Habeeballah, T. (2013). Air microbial contamination at the holy mosque, Makkah, Saudi Arabia. Current World Environment, 8(2), 179-187.

Hussin, M., Ismail, M. R., \& Ahmad, M. S. (2017). Air-conditioned university laboratories: Comparing $\mathrm{CO}_{2}$ measurement for centralised and split-unit systems. Journal of King Saud UniversityEngineering Sciences, 29(2), 191-201.

Jamaludin, N., Mohammed, N. I., Khamidi, M. F., \& Wahab, S. N. A. (2015). Thermal comfort of residential building in Malaysia at different micro-climates. Procedia-Social and Behavioral Sciences, 170, 613-623.

Kanchongkittiphon, W., Mendell, M. J., Gaffin, J. M., Wang, G., \& Phipatanakul, W. (2015). Indoor environmental exposures and exacerbation of asthma: An update to the 
2000 review by the Institute of Medicine. Environmental Health Perspectives, 123(1), 6-20.

Kasim, N. F. M., Zaki, S. A., Ali, M. S. M., Ikegaya, N., \& Razak, A. A. (2016). Computational study on the influence of different opening position on wind-induced natural ventilation in urban building of cubical array. Procedia Engineering, 169, 256-263.

Kubba, S. (2009). LEED practices, certification, and accreditation handbook. ButterworthHeinemann. 211-269.

Kubota, T., \& Toe, D. H. C. (2015). Application of passive cooling techniques in vernacular houses to modern urban houses: A case study of Malaysia. Procedia-Social and Behavioral Sciences, 179, 29-39.

Laurini, E., Taballione, A., Rotilio, M., \& De Berardinis, P. (2017). Analysis and exploitation of the stack ventilation in the historic context of high architectural, environmental and landscape value. Energy Procedia, 133, 268-280.

Li, Y., Fu, H., Wang, W., Liu, J., Meng, Q., \& Wang, W. (2015). Characteristics of bacterial and fungal aerosols during the autumn haze days in Xi'an, China. Atmospheric Environment, 122, 439-447.

Li, Z., Wang, H., Zheng, W., Li, B., Wei, Y., Zeng, J., \& Lei, C. (2019). A tracing method of airborne bacteria transmission across built environments. Building and Environment, 164, 1-8.

Lim, F. L., Hashim, Z., Said, S. M., Than, L. T. L., Hashim, J. H., \& Norbäck, D. (2015). Sick Building Syndrome (SBS) among office workers in a Malaysian universityassociations with atopy, fractional exhaled nitric oxide (FeNO) and the office environment. Science of the Total Environment, 536, 353-361.

Lyng, H., Gunnarsen, L., \& Andersen, H. V. (2015). The effect of ventilation on the indoor air concentration of PCB: An intervention study. Building Environment, 94, 305-312.

Mahyuddin, N., \& Awbi, H. (2012). A review of $\mathrm{CO}_{2}$ measurement procedures in ventilation research. International Journal of Ventilation, 10(4), 353-370.

McGill, G., Oyedele, L. O., \& McAllister, K. (2015). Case study investigation of indoor air quality in mechanically ventilated and naturally ventilated UK social housing. International Journal of Sustainable Built Environment, 4(1), 58-77.

Mendell, M. J., Mirer, A. G., Cheung, K., Tong, M., \& Douwes, J. (2011). Respiratory and allergic health effects of dampness, mold, and dampness-related agents: A review of the epidemiologic evidence. Environmental Health Perspectives, 119(6), 748-756.

NIOSH. (1998). National Institute for Occupational Safety and Health. Bioaerosol sampling (indoor air) 0800: Culturable organisms bacteria, fungi, thermophilic actinomycetes, in Issue 1, 1998. NIOSH Manual of Analytical Methods (NMAM), $4^{\text {th }}$ ed.

NIOSH. (2016). National Institute for Occupational Safety and Health. 'Indoor Air Quality Assessor' [PowerPoint Presentation]. NIOSH-PDD-CS-IAQ.

Ocak, Y., Kılıçvuran, A., Eren, A. B., Sofuoglu, A., \& Sofuoglu, S. C. (2012). Exposure to particulate matter in a mosque. Atmospheric Environment, 56, 169-176.

Othman, M., Latif, M. T., Yee, C. Z., Norshariffudin, L. K., Azhari, A., Halim, N. D. A., Alias, A., Sofwan, N. M., Abd Hamid, H. H., \& Matsumi, Y. (2020). PM $_{2.5}$ and ozone in office environments and their potential impact on human health. Ecotoxicology and Environmental Safety, 194, 1-9.

Park, D. U., Yeom, J. K., Lee, W. J., \& Lee, K. M. (2013). Assessment of the levels of airborne bacteria, gram-negative bacteria, and fungi in hospital lobbies. International 
Journal of Environmental Research and Public Health, 10(2), 541-555.

Pérez-Lombard, L., Ortiz, J., \& Pout, C. (2008). A review on buildings energy consumption information. Energy and Buildings, 40(3), 394-398.

Prihatmanti, R., \& Bahauddin, A. (2014). Indoor air quality in adaptively reused heritage buildings at a UNESCO World Heritage Site, Penang, Malaysia. Journal of Construction in Developing Countries, 19(1), 69-91.

Rasli, N. B. I., Ismail, M. R., Ramli, N. A., Shith, S., Mohamad Nazir, A. U., Md Yusof, N. F. F., \& Zainordin, N. S. (2019). Compliance of indoor air contaminants within the main prayer halls of mosques in Malacca with Malaysia's indoor air quality standard. Journal of Construction in Developing Countries, 24(2), 105-121.

Rasli, N. B. I., Ramli, N. A., Ismail, M. R., \& Shith, S. (2019). The dependency of biological contaminants on temperature and relative humidity within praying halls of mosques. Sains Malaysiana, 48(8), 15751581.

Rasli, N. B. I., Ramli, N. A., Ismail, M. R., Md Yusof, N. F. F., F. M., Shith, S., Mohammad Kamaruddin, N., Salleh, M. B., \& Mohamad Nazir, A. U. (2019). Smoke flow visualisation testing on window panel at various wind speed and pores: A wind tunnel study. Journal of Sustainability Science and Management, 14(6), 66-79.

Rasli, N. B. I., Ramli, N. A., Ismail, M. R., Md Yusof, N. F. F., Zainordin, N. S., Mohamad Nazir, A. U., \& Shith, S. (2019). Indoor chemical air contaminants in the main prayer hall during Jumaat prayer in mosques with different mechanical ventilation. International Journal of Integrated Engineering, 11(1), 084-091.

Rasli, N. B. I., Ramli, N. A., Ismail, M. R., Shith, S., Md Yusof, N. F. F., Zainordin, N. S., El-Bayoumi, M., \& Mohamad
Nazir, A. U. (2017). Effects of hoovering activities on biological contaminants and particulate matter levels in main prayer halls of Malaysian mosques. Current World Environment, 14(1), 134-142.

Salleh, N. M., Kamaruzzaman, S. N., Riley, M., Zawawi, E. M. A., \& Sulaiman, R. (2015). A quantitative evaluation of indoor environmental quality in refurbished kindergarten buildings: A Malaysian case study. Building and Environment, 94, 723733.

Salonen, H., Salthammer, T., \& Morawska, L. (2018). Human exposure to ozone in school and indoor office environments. Environment International, 119, 503-514.

Salonen, H. J., Pasanen, A. L., Lappalainen, S. K., Riuttala, H. M., Tuomi, T. M., Pasanen, P. O., Bäck, B., \& Reijula, K. E. (2009). Airborne concentrations of volatile organic compounds, formaldehyde and ammonia in Finnish office buildings with suspected indoor air problems. Journal of Occupational and Environmental Hygiene, 6(3), 200-209.

Spiru, P., \& Simona, P. L. (2017). A review on interactions between energy performance of the buildings, outdoor air pollution and the indoor air quality. Energy Procedia, 128, 179-186.

Tang, H., Ding, J., Li, C., \& Li, J. (2019). A field study on indoor environment quality of Chinese inpatient buildings in a hot and humid region. Building and Environment, 151, 156-167.

Thach, T. Q., Mahirah, D., Dunleavy, G., Nazeha, N., Zhang, Y., Tan, C. E. H., Roberts, A. C., Christopoulos, G., Soh, C. K., \& Car, J. (2019). Prevalence of sick building syndrome and its association with perceived indoor environmental quality in an Asian multi-ethnic working population. Building and Environment, 166, 1-8.

USEPA. (2017). United State of Environmental Protection Agency. Indoor air quality 
(IAQ): Volatile organic compounds' impact on indoor air quality. https://www.epa.gov/ indoor-air-quality-iaq/volatile-organiccompounds-impact-indoor-air-quality.

Vasile, V., Petran, H., Dima, A., \& Petcu, C. (2016). Indoor air quality-a key element of the energy performance of the buildings. Energy Procedia, 96, 277-284.

Vornanen-Winqvist, C., Järvi, K., Toomla, S., Ahmed, K., Andersson, M. A., Mikkola, R., Marik, T., Kredics, L., Salonen, H., \& Kurnitski, J. (2018). Ventilation positive pressure intervention effect on indoor air quality in a school building with moisture problems. International Journal of Environmental Research and Public Health, 15(2), 1-23.

Xie, Z., Li, Y., Lu, R., Li, W., Fan, C., Liu, P., Wang, J., \& Wang, W. (2018). Characteristics of total airborne microbes at various air quality levels. Journal of Aerosol Science, 116, 57-65.
Yau, Y. H., \& Hasbi, S. (2017). A comprehensive case study of climate change impacts on the cooling load in an air-conditioned office building in Malaysia. Energy Procedia, 143, 295-300.

Yu, L., Jia, J., Chen, S., Lu, Q., \& Feng, G. (2017). Characteristics of the concentration change of the particulate matter in the indoor and outdoor existing public office buildings. Procedia Engineering, 205, 3367-3372.

Zhou, L., \& Haghighat, F. (2009). Optimisation of ventilation system design and operation in office environment, Part I: Methodology. Building and Environment, 44(4), 651-656.

Zock, J. P., Jarvis, D., Luczynska, C., Sunyer, J., \& Burney, P. (2002). Housing characteristics reported mould exposure and asthma in the European community respiratory health survey. Journal of Allergy and Clinical Immunology. 110(2), 285-292.

\section{Appendix A}

\section{Questionnaire for Building \\ Occupants}

1) General Information

Date :

Building/Company Name :

Department/Division :

Has your Company carried out any assessment related to IAQ:

Yes

No

In progress

Not sure 
2) Background Factor

Sex:

Male

Female
Age:

$$
<25 \text { yrs }
$$

$25-39 \mathrm{yrs}$

40 - $55 \mathrm{yrs}$

$>55$ yrs

3) Nature of Occupation

Occupation/Position:

How long have you been at your present place of work?

No. of hours spent per day at your main workstation :

Brief description of your work:

4) Environmental Conditions

Type of workstation:

Enclosed room

Open concept

No. of people sharing your workstation:

How is your area air-conditioned:

Central unit

Local unit (spilt unit)

Please indicate if you work near the following equipment:

Everyday

2-3 times weekly

Never
a) Typewriter
b) Video display unit/computer
c) Photocopier
d) Fax machine 
Have you been bothered during the last three (3) months by any of the following factors at your workstation/workplace?

$$
\text { Yes, often (every week) } \quad \text { Yes, } \quad \text { No, never }
$$
a) Draught
b) Room temperature too high
c) Varying room temperature
d) Room temperature too low
e) Stuffy "bad" air
f) Dry air
g) Unpleasant odour
h) Passive smoking
i) Dust and dirt

5) Past/Present Diseases/Symptoms

Yes $\quad$ No

Have you ever had asthmatic problems?

If yes, during last year?

Have you ever suffered from sinusitis?

If yes, during last year?

Have you ever suffered from eczema?

If yes, during last year?

\section{6) Present Symptoms}

During the last three months, have you had any of the following symptoms at work:

$$
\begin{array}{ccc}
\text { Yes, often } & \text { Yes, sometimes } & \text { No, never } \\
\text { (every week) } & (2-3 \text { times/week })
\end{array}
$$
a) Headache
b) Feeling heavy-headed
c) Fatigue/lethargy
d) Drowsiness 
e) Dizziness

f) Nausea/vomiting

g) Cough

h) Irritated, stuffy nose

i) Hoarse, dry throat

j) Skin rash/itchiness

k) Irritation of the eyes

1) Scaling/itching scalp or eras

No of days in the past one (1) month that you had to take off work because of these complaints:

When do these complaints occur?

Mornings

Afternoons

No noticeable trend

When do you experience relief from these complaints?

After I leave my workstation

After I leave the building

No noticeable trend

If female, are you currently pregnant?

Yes

No

Not sure 